\title{
Pastorace v domově pro seniory: vybrané otázky ${ }^{1}$
}

\section{Věra Suchomelová}

„Všechno má určenou chvíli a veškeré dění pod nebem svůj čas..." (Kaz 3,1-8). Stář́í a zejména takzvaný čtvrtý věk staví člověka před zásadní úkoly a výzvy, pro jejichž zvládání je ten „správný čas“ právě na vrcholu životní cesty. Je čas (nejvyšší a poslední) dořešit nedořešené, uzdravit zraněné, ukončit započaté, napravit pokažené, otevř́t uzavřené, dotvořit a zhodnotit život. ${ }^{2}$ Stáŕí tak dává svému nositeli šanci život zhodnotit a naplnit, zároveň však kumuluje životní ztráty a obtíže v mnoha oblastech. Metaforicky řečeno, stáří je obdobím sklizně životních plodů, některé ovšem mohou být jen těžko poživatelné. Také proto Jan Pavel II. označuje stář́ za jednu „z nejtěžších kapitol velkého umění žít“. ${ }^{3}$ $S$ ohledem na tyto skutečnosti se pastorace seniorů jeví nejen jako potřebná, ale prrímo jako životně důležitá.

Patrně nejčastěji citovaná věta předmluvy encykliky Gaudium et spes apeluje na nezbytnost zájmu všech křestanů o radosti a naděje, smutky a úzkosti lidí naší doby, a to nejen na „církevní půdě“. Pastoraci seniorů tak lze charakterizovat jako doprovázení staršího člověka (nejen věřícího či př́mo tradičně religiózního křestana) v hledání směru jeho života, životním bilancování ve vlastním duchovním rozvoji i v př́pravě na smrt, jako pomoc k lidsky důstojnému zvládání náročných životních okamžiků a krizí; to vše s respektem k jedinečnosti daného člověka včetně jedinečnosti jeho spirituality a $\mathrm{v}$ jakémkoli prostředí. ${ }^{4} \mathrm{P}$. Ambros mluví o pastoračním charismatu jako o „umění doprovázet člověka v dějinách jeho života a víry".5 Životním prostředím mnoha starších lidí, zvláště těch s omezenou soběstačností, jsou domovy pro seniory. Specifika institucionalizovaného bydlení se bezesporu promítají do dějin života i víry a mohou umocňovat některé těžkosti se stář́m související. Můžeme se tedy ptát, jak se prostředí rezidenčního zařízení promítá do způsobu pastorace a budování vztahu mezi pastorujícím (pastoračním pracovníkem) ${ }^{6}$ a pastorovaným.

Následující text vychází z dílčích závěrů kvalitativní studie Duchovnípotřeby v životějihočeských senioru, ${ }^{7}$ realizované v rámci disertační práce autorky. ${ }^{8}$ Cílem je jednak reflektovat současnou praxi $\mathrm{v}$ oblasti pastorace $\mathrm{v}$ domovech pro seniory, jednak na základě analýzy kvalitativních dat a $s$ ohledem na zmíněné pojetí pastorace seniorů formulovat některá doporučení do pastorační praxe (nejen) v domovech pro seniory.

\footnotetext{
1 Tato studie vznikla v rámci projektu specifického výzkumu GAJU 117/2013/H - Pojetí kvality sociální práce v souvislosti se sebedefinováním sociálního pracovníka a jeho pomáhající profese.

2 Srov. Aleš OPATRNÝ, Pastorace zulástních skupin, Červený Kostelec: Pavel Mervart, 2014, s. 34.

3 JAN PAVEL II., Nebojme se pravdy: nedostatky lidí a provinèní církve, Praha: Zvon, 1997, s. 73.

4 Srov. širší definici pastoračního jednání, jak ji uvádí Aleš OPATRNÝ, Pastorace zuláštních skupin, s. 16.

5 Srov. Pavel AMBROS, Fundamentální pastorální teologie, Olomouc: Univerzita Palackého, 2002, s. 117.

6 V určitém smyslu může být pastorujícím jakýkoliv křestan v blízkosti seniora, v závislosti na své lidské a duchovní zralosti. $\mathrm{V}$ případě hlubších otázek, zranění $\mathrm{z}$ duchovní oblasti či obecně otázek obtíží v duchovní oblasti je nezbytná intervence „duchovně kompetentní" osoby s patřičným vzděláním. V české realitě se v tomto př́ípadě jedná zejména o duchovního konkrétní církve či pastoračního asistenta.

7 Stěžejní data výzkumu tvořily hloubkové rozhovory s dvaceti seniory staršími sedmdesáti pěti let, doplněné terénními poznámkami z prímého pozorování fyzického prostředí a sociálního klimatu ve dvou rezidenčních zařízeních (uvedené pod fiktivními názvy Zálesí a Jiř́kov). Sběr dat probíhal od ledna 2012 do června 2013. Komunikačními partnery byli senioři starší sedmdesáti pěti let, polovinu z nich tvořili obyvatelé domova pro seniory. Tematická analýza dat se odvíjela od doslovné transkripce.

8 Věra SUCHOMELOVÁ, Senioři a spiritualita: duchovnípotřeby v každodenním životě, České Budějovice, 2015, disertační práce, Jihočeská univerzita, Teologická fakulta, Katedra pedagogiky.
} 


\section{Pastorace v domovech pro seniory: reflexe současné praxe}

Tuzemské domovy pro seniory lze - s určitou nadsázkou - považovat za misijní území. Duchovní péče $\mathrm{v}$ těchto rezidenčních zařízeních není (na rozdíl např́klad od německy mluvících sousedních zemí) koncepčně ošetřena. Na jedné straně je tak závislá na dobré vưli managementu a aktuálních finančních možnostech daného zařízení, na straně druhé na možnostech a ochotě církví se na této péči podílet. Pokud dané zařízení avizuje nějakou formu duchovní péče, většinou je touto péčí myšlen určitý „servis“ pro seniory, kteří se prezentují jako věrící a sami projeví zájem o religiózní praktiky. ${ }^{10}$ Součástí života daného zařízení je např́klad slavení eucharistie či bohoslužba nekatolické církve jednou $\mathrm{v}$ měsíci, jednou týdně návštěvy akolytů přinášejících eucharistii těm, kdo o ni požádají, či zprostředkovaná návštěva duchovního na vyžádání konkrétního seniora. Za této situace církev spíše reaguje na „poptávku“ a pastýřsky působí zejména na tradičně religiózní křestany, kteří jsou i v rezidenčním zařízení v kontaktu se spolufarníky (př́padně s duchovním) z původního bydliště, aktivně projevují zájem o účast na svátostech, čerpají posilu $\mathrm{z}$ duchovních textů a podobně. ${ }^{11}$ Tento postoj označuje Schlemmer za nesmyslné cílení pastorace zejména dovnitř vlastní církve v rámci jakéhosi sebezáchovného, udržovacího procesu. ${ }^{12}$

Analýza kvalitativních dat ukázala limity takto pojaté pastorace. Přestože do obou zařízení, ve kterých výzkum probíhal, docházel duchovní i pastorační asistent, nikdo z dotazovaných je jako partnery k duchovnímu rozhovoru nezmínil a za tímto účelem nevyhledal. Ani senioři prezentující sami sebe jako věřící neuvedli tyto „duchovní profesionály“ jako někoho, s kým by bylo možné sdílet životní těžkosti, řešit otázky vztahující se $\mathrm{k}$ existenciálním tématům či jednoduše navázat bližší vztah (na rozdíl od sester, aktivizačních pracovnic a přátel). Jednou z př́ičin může být skutečnost, že pastorační pracovníci byli seniory vnímáni zejména jako nositelé určité „nepřekročitelné“ role. Pastorační asistent byl zejména „ten, který podává“, pastorační asistentka „ta, která vede růženec“, a kněz „ten, který slouží mši“. Tuto domněnku může podpořit úryvek z rozhovoru autorky (S) s paní Marií ( $M, 85$ let), věřící, dosud činorodou, ale velmi osamělou ženou z domova v Zálesí.

S: „A tam (pozn.: po pravidelné středeční boboslužbě slova) si mưřete popovídat, třeba když tam chodite za tím, nebo třeba když byste chtèla nèco probrat, co by vás třeba trápilo, nebo mèla jste néco $v$ blavè, tak müřete to probrat s tím panem $P$. (pastoračním asistentem)?"

M: „Ne, ten jenom právě prijiede, obejde toble, má tam asi dvě babičky, kterým podává..."

S: „Takžre on spís chodí a podává."

M: "Jenom podává, no, jinak ne."

S: „A ta pani P. (pastorační asistentka, maň̌elka pana P.) ta jenom popovídat, to taky není?" $M:$ „Ne, ta jenom prijide na ten rư̌̆̌nec."

\footnotetext{
9 V této části textu se autorka opírá nejen o terénní pozorování v domovech Zálesí a Jiř́íkov, ale zejména o informace získané cestou neformálního dotazování pracovníků domovů pro seniory v rámci kurzů dalšího vzdělávání, konferencí apod.

10 Zúžené pojetí duchovní péče odráží běžný pohled na duchovní potřeby ze strany nejen laické, ale často i odborné veřejnosti či místní církve.

11 Srov. Aleš OPATRNÝ, Pastorace zuláštních skupin, s. 20.

12 Srov. Karl SCHLEMMER, Českobudějovické teze k pastoraci budoucnosti, in: Pronikavá změna pastorace nebo sebezáchovný provoz? Být církví misionárškým zpuisobem: mezinárodní pastorálně teologické sympozium, eds. Zdeněk DEMEL - Karl SCHLEMMER, České Budějovice: Teologická fakulta Jihočeské univerzity, 2005, s. 139.
} 
Paní Marie vůbec neuvažovala (či se neodvažovala uvažovat?), že by se někomu $z$ nich mohla či měla svěřit s těžkostmi a otázkami pramenícími z jejího stáríí, osamělosti, nejistoty, zklamání. Je tedy otázkou, zda se religiózní senioři skutečně mají na koho obrátit, pocitují-li potřebu (často nevyřčenou) duchovního rozhovoru či doprovázení, pokud je nenavštěvuje např́klad duchovní z jejich domovské farnosti. V ještě větším „Vzduchoprázdnu“, co se duchovní pomoci a doprovázení týče, se pak nalézají senioři, kteří se prezentují jako nevěřící či ateisté nebo pocitují nějaký blok ve vztahu k církvi. Ve vztahu ke zmíněným zařízením lze předpokládat, že by pastorační pracovníci byli lidsky i odborně schopni a ochotni seniory v jejich situaci doprovázet - pokud by ovšem byli osloveni...

Můžeme shrnout, že čeští senioři, prožívající závěrečnou fázi svého života $\mathrm{v}$ běžném rezidenčním zařízení, mají dostupnou kvalitní zdravotní péči a množství volnočasových a terapeutických aktivit, ale $\mathrm{v}$ nejdůležitějších oblastech svého života zůstávají často bez pomoci a osamělí.

\section{Pastorace seniorů jako (v první řadě) vztah}

Pastorace seniorů znamená v první řadě vztah a komunikaci, stejně jako víra či spiritualita. Ústřední témata tohoto vztahu reflektují mnohé pokoncilní církevní dokumenty, spojené zejména s osobou Jana Pavla II., ${ }^{13}$ ale i např́klad Závěrečný dokument plenárního sněmu katolické církve v ČR. ${ }^{14}$ Pro doprovázejícího (pastorujícího) znamená tento vztah nejen dávat - tedy chápat, respektovat, pomáhat a podporovat, objevovat duchovní dimenzi ve starostech, úkolech a výzvách -, ale také se nechat obdarovat osobností a životním př́během doprovázeného. ${ }^{15} \mathrm{Na}$ této bázi navázaný vztah dává bezpečný prostor nejen ke sdílení všednodenních starostí a radostí, ale také k nejhlubším otázkám, které si dnešní senior klade stejně jako kdysi bibličtí starci: „Jaký je smysl bolesti, zla, smrti? Nač ona vítězství, tak draze dosažená? Co přijde po tomto pozemském světěe" "16 $\mathrm{Na}$ základě závěrů přehledové i analytické části kvalitativní studie Duchouní potřeby $v$ životě jibočeských senioru a s odkazem na uvedené vymezení pastorace bylo možné charakterizovat několik aspektů pastorace starších lidí (nejen) v domovech pro seniory.

\section{Vlastní iniciativa v navázání kontaktu}

Jak už bylo řečeno, žádný z participantů výzkumu, at religiózních či nereligiózních, žijících v domě pro seniory či ve vlastním bytě, nejmenoval duchovního či pastoračního asistenta jako osoby, jimž by mohl svěřit své otázky či obavy a s kým by mohl mluvit o svých obtížích. Př́činou této skutečnosti může být určitý ostych před „církevní autoritou“ a zároveň nejasná představa o kompetencích kněze či pastoračního asistenta. Senioři religiózně socializovaní v předkoncilní církvi obvykle nebyli a nejsou zvyklí navazovat prátelské, důvěrné vztahy s duchovním (což není až tak výjimečné mezi současnou mladou a stř̌ední generací).

13 Srov. např́klad dokument PAPEŽSKÁ RADA PRO LAIKY, Düstojnost seniora a jeho poslání v církvi a ve světě, Praha: Česká biskupská konference, 2010; nebo JAN PAVEL II., List starým lidem, Praha: Česká biskupská konference, 1999.

14 Srov. Život a poslání křestáan v církvi a ve světě, Závěrečný dokument Plenárního sněmu katolické církve v ČR, Kostelní Vydří: Karmelitánské nakladatelství, 2007.

15 K tématu více Aleš OPATRNÝ, Pastorace zuláštních skupin; nebo také Vladimír BOUBLÍK, Teologická antropologie: clověk v Kristu Ježísíi, Kostelní Vydří: Karmelitánské nakladatelství, 2006, s. 80.

16 Srov. Dokumenty II. vatikánskébo koncilu, Kostelní Vydří: Karmelitánské nakladatelství, 2002. Konstituce Gaudium et spes, čl. 10. Dále v textu pouze GS a číslo př́islušného oddílu. 
Analýza dat také poodhalila důvod, proč se mnozí senioři, ač křestané, $s$ duchovním, který do domova pro seniory dochází, vůbec nemusejí setkat. Její závěry potvrdily jinými autory ${ }^{17}$ deklarovanou preferenci soukromého proživání religiozity ve vyšším věku na úkor participace v církevním společenství, a to i u tradičně religiózních seniorů. Osobní spiritualita či víra znamená pro mnohé seniory zejména vnitřní prostor, ve kterém jsou oni sami s Bohem, se svými blízkými, se svými ideály a tužbami, které je přesahují. Preference prožívání religiozity v soukromí může mít několik příčin. Za prvé se může jednat o přirozenou tendenci ke ztišení a kontemplaci ve vlastním nitru ve smyslu Tornstamovy gerotranscendence, charakterizující stáří jako transcendentní samo o sobě, pro něž je typické stírání hranic mezi minulostí, současností a budoucností, pokles zájmu o materiálno a povrchní vztahy a naopak zvýšená potřeba osamělého rozjímání. ${ }^{18} \mathrm{Za}$ druhé může jít o potřebu určitého vnitřního prostoru jako úkrytu před ohrožujícím či zahanbujícím prostředím, soukromého místa, ve kterém není atakována lidská důstojnost, kde se člověk setkává s Bohem i se svými blízkými, kde může být sám sebou, kde není zraňována láska, kde je stále prostor pro víru a naději. Za třetí zde mohou hrát roli minulá zranění související s církevní praxí a následná ztráta důvěry $\mathrm{v}$ církev jako instituci; za čtvrté to může být prostá nechut setrvávat ve společnosti lidí, kteř́ jsou člověku nepř́íjemní a které přesto musí denně potkávat či s nimi dokonce sdílet jeden pokoj.

V neposlední řadě mohou být příčinou více či méně „technické“ důvody, bránící staršímu člověku plně participovat na společenství: nevhodné prostory (např́klad jídelna s nepohodlnými židlemi) nebo nedostatečný respekt pastoračního pracovníka ke smyslovému či kognitivnímu omezení vedoucímu ke komunikačním bariérám. Př́kladem může být úryvek z rozhovoru s paní Stelou (79) z domova v Jiř́k ově, věrící ženou s mnoha fyzickými obtížemi. Stela svůj negativní postoj k participaci na církevním společenství $\mathrm{v}$ domově nejdříve zdůvodnila obecnou nedůvěrou k duchovním, vzápětí ale zmínila zcela praktické důvody - smyslové omezení: „Máme tady kapli, pan faráŕ sem chodí jednou za tejden nebo za čtrnáct dní. Já ho neslyšim, co povídá. Já špatně vidim...(...) Tak jsem $z$ toho ani nic neměla. Tak ř́kám, co tam mám sedět, sedět a jenom takhle koukat."

Můžeme shrnout, že stejně jako Bůh přichází vstříc člověku, ${ }^{19}$ tak i pastorující musí potřebným sám vyjít vstříc, a to způsobem, který jsou schopni pochopit a přijmout. Určitá „depistáž“ potřebných a navázání prvního kontaktu musí jednoznačně vycházet z iniciativy pastoračního pracovníka, což je v rámci domova pro seniory bezesporu snazší než v př́padě osamělých lidí žijících ve vlastním bytě.

\section{Láska k bližnímu jako východisko}

Závěry výzkumné studie nenaznačily výrazné rozdíly v intenzitě a zakoušení duchovních potřeb mezi obyvateli rezidenčního zařízení a seniory žijícími ve vlastním prostředí až na jednu výjimku: obyvatelé domova pro seniory zakoušeli výrazně intenzivněji potřebu lásky, a to jak ve smyslu lásku přijímat, tak ve smyslu obdarovávat, tedy lásku dávat, být užitečný.

17 Srov. Walter FÜRST a kol., „Selbst die Senioren sind nicht mebr die alten... “Praktisch-theologische Beiträge zu einer Kultur des Alterns, Münster: Lit Verlag, 2003.

18 Srov. Lars TORNSTAM, Gerotranscendence - a theory about maturing into old age, Journal of Aging and Identity 1/1996, s. $37-50$.

19 Srov. Katechismus katolické církve, vyd. 2., Kostelní Vydř́i: Karmelitánské nakladatelství, 2002, s. 50-67. 
$\mathrm{V}$ prostředí, které často atakuje lidskou důstojnost (zejména $\mathrm{v}$ př́padě nedobrovolně sdílených pokojů), se starší člověk o to víc potřebuje cítit přijímán, respektován, potřebuje se cítit jako ten, který má co dát a který ještě může být užitečný. Potřebuje vědět, že je milován, potřebuje zakoušet Boží lásku. Zralý křestanský postoj pastorujíćího umožňuje „obdařit ho pohledem lásky, který tolik potřebuje“. ${ }^{20}$ Benedikt XVI. připomíná úzkou souvislost lásky k Bohu a lásky k bližnímu. ${ }^{21}$ Pastorace v tomto smyslu znamená „být s člověkem“, nevázat péči a zájem na dosažení určitého cíle, respektovat jeho jedinečnost včetně jeho jedinečného a originálního vztahu $\mathrm{k}$ Bohu a úrovně jeho víry. Takovým způsobem pojatá pastorace dává starému člověku hodnotu, důstojnost, pomáhá mu uchovávat naději a víru. $\mathrm{Na}$ empatii, úctu a lásku jako podstatu jakékoliv pastorační činnosti odkazuje již zmíněná první věta předmluvy konstituce Gaudium et spes: „vždyt' přece není nic opravdu lidského, co by nenašlo odezvu v srdcích Kristových učedníkü“.22

Setkání s druhým člověkem může být i ve stáří spouštěčem rozhodného kroku na cestě $\mathrm{k}$ duchovní zralosti. ${ }^{23}$ Bezpodmínečnou lásku, respekt a úctu k bližnímu ukotvenou v lásce k Bohu lze považovat za jakési „stěžejní kanály“ pastorace seniorů.

\section{Otevřenost}

Láskyplná duchovní intervence pomáhá jakémukoliv staršímu člověku (tedy nejen tomu, který se prezentuje jako věŕící) na cestě rozvoje jeho osobní spirituality a přináší mu to nejpřesvědčivější svědectví o lásce Boha k člověku. Papež František apeluje na neutuchající misijní aktivitu s respektem $\mathrm{k}$ její variabilitě: „....nicméně všichni jsme pozváni přijmout toto povolání - vykročit z vlastního pohodlí a mít odvahu vydat se do všech periferií, které potřebují světlo evangelia“. ${ }^{24}$

V určitém smyslu bychom mohli za takovou „periferii“ považovat i pokoje domova pro seniory, jejichž obyvatelé nepatř́ $\mathrm{k}$ tradičně religiózním křestanům a výslovně nežádají eucharistii ani jiné svátosti, př́padně těch křestanů, kteří nežijí v kontaktu s církví a svou religiozitu praktikují v mezích svého bytu a ve svém nitru, nebo dokonce, ač religiózně socializovaní, svou víru zcela nebo částečně ztratili. Pokud se duchovní pastýř zaměřuje systematicky pouze na malou skupinu svých stálých a osvědčených „oveček“, těžko lze $\mathrm{v}$ tomto př́padě mluvit o misijní dynamičnosti ${ }^{25}$ či církvi otevřených dveř́i. ${ }^{26}$

Otevřenost spočívá i v oproštění se od skrytého či přiznaného cíle pastorace - např́klad konverze či návratu „do lůna církve“. ${ }^{27} \mathrm{Na}$ druhou stranu, přestože pastorační péči rozhodně nelze zaměňovat $s$ cílenou katechezí, pastorující by se neměl snažit ani o jakousi

20 BENEDIKT XVI., Deus caritas est, Praha: Paulínky, 2006, čl. 18. Dále v textu pouze DCE a číslo př́islušného oddílu.

21 Srov. DCE čl. 17.

22 GS čl. 1.

23 Srov. Walter FÜRST a kol., „,Selbst die Senioren sind nicht mebr die alten... “, s. 83. Fürst a kolegové na základě rozsáhlé kvalitativní studie se staršími dospělými označili za nejvýraznější spouštěče změn v oblasti religiozity vedle náročných životních okamžiků setkání s konkrétními lidmi.

24 FRANTIŠEK, Evangelii gaudium. Radost evangelia: apoštolská exbortace o blásání evangelia v současném světě, Praha: Paulínky, 2014, čl. 20.

25 Tamtéž, čl. 48.

26 Tamtéž, čl. 46.

27 Srov. Aleš OPATRNÝ, Malá příručka pastorační péče o nemocné, Praha: Pastorační středisko Arcibiskupství pražského, 2003 , s. 8. 
„náboženskou neutralitu“. Jeho vnitřní síla totiž pramení nejen z jeho osobnostních kvalit, ale zejména $\mathrm{z}$ jeho vlastní identity křestana. $\mathrm{V}$ tomto smyslu upozorňuje Aleš Opatrný na podstatu pastorační péče, která „nepředstavuje ani jen řeč o Bohu, víré, eventuálně svátostech, a není to také řeč jen a jen obecně lidská, ve které se vyhneme jakékoli zmínce o Bohu“.28

Můžeme shrnout, že potřeba naplnění $\mathrm{v}$ oblasti duchovních potřeb je společná všem seniorům nezávisle na jejich (ne)deklarovaném náboženském vyznání či denominaci. Pastorační pracovník musí být fyzicky, mentálně i duchovně přítomen pro všechny seniory v duchu působení Ježíše Krista, zejména pro ty „nemocné“ (Mt 9,12-13), tedy ne pro konstantní skupinu věrných „kostelních“ věřících.

\section{Aktivní naslouchání}

Pastorační pracovník by se měl zorientovat $\mathrm{v}$ životním příběhu konkrétního člověka, aby mohl pochopit jeho př́stup $\mathrm{k}$ víre, $\mathrm{k}$ religiozitě, $\mathrm{k}$ participaci na církevních obřadech. Nejedná se přitom o jakousi hloubkovou analýzu životní historie, spíše o ochotu dát staršímu člověku čas a prostor pro vyjádření vlastního životního př́běhu. K aktivnímu naslouchání jako výchozímu bodu jakékoli křestanské intervence odkazuje v určitém smyslu i koncilní dokument o misiích, jehož jedenáctý článek nese stručný název „Být a hovořit s lidmi“.29

V rozhovoru se starým člověkem, jehož silnou potřebou je sdílet svůj životní příběh, zvlášt platí Kazatelovo: „je čas mlčet i čas mluvit“ (Kaz 3,7). Aktivní naslouchání pomáhá odhalit skutečné př́činy dlouhodobě posilovaných a verbálně deklarovaných negativních religiózních (i nereligiózních) postojů i rozpory v konzistenci vnějš́ho a vnitřního prožívání křestanské spirituality, tedy nedostatky v základních principech křestanské spirituality, jak je definuje např́ílad J. P. Ondok. ${ }^{30}$ Pastorující je tak nepostradatelným průvodcem na cestě člověka ke spáse, protože, jak uvádí Gaudium et spes, „rozpor, který je u mnoha lidí mezi vírou, ke které se hlásí, a denním životem, je třeba počítat mezi nejzávažnější omyly naší doby. “31 Starší člověk mohl v podobném rozporu prožít mnohá desetiletí, aniž by si ho byl vědom a aniž by s ním někdo na toto téma mluvil.

Aktivní naslouchání také umožní pastorujícímu odhalit jazyk, jímž senior ve vztahu k religiozitě mluví. „Nevíra“, „ateismus“, nebo naopak „víra“ mohou být chápány mnoha způsoby, které bez znalosti osobní historie člověka a př́iběhu jeho víry není možné rozkrýt. $\mathrm{V}$ tomto smyslu A. Opatrný ${ }^{2}$ poukazuje na nutnou obezřetnost při dělení lidí na "veréící a „nevěřícíc. „Nevěřící mohou být jednak lidé, již skutečně víru v Boha nepřijímají, ale také to mohou být ti, kteři mají negativní vztah ke katolické církvi, k církvi obecně či celkově k nějaké formě náboženství, ale s Bohem nějakým způsobem „počítaji". Takto deklarovanou variabilitu „nevíry“ potvrdily i závěry výzkumné studie Duchovní potřeby v životě jibočeských seniori̊, na jejichž základě lze doplnit ještě jeden možný postoj těch, již sami sebe prezentují

28 Tamtéž.

29 Dokumenty II. vatikánskébo koncilu, Praha: ZVON, Ad gentes, čl. 11.

30 Srov. Josef Petr ONDOK, Čmelák asketický: Úvaby o křestanské spiritualitě, Svitavy: Trinitas, 2003, s. 45.

31 GS čl. 43.

32 Srov. Aleš OPATRNÝ, Pastorace zuláš́tních skupin, s. 21. 
ako „nevěříci“. Mohou to být lidé, kteří by s Bohem rádi „počítali“ a cítili jeho přítomnost ve svém životě, ale vzhledem ke zraněním, neporozumění či neznalosti se jim tento vztah nepodařilo navázat. Důvody jejich postoje jsou často téměř nevyřčené, případně řečené „mezi řádky“, a pozorné a trpělivé naslouchání je tak jedinou cestou, jak tyto nuance správně pochopit a zhodnotit vzhledem $\mathrm{k}$ dalšímu pastoračnímu postupu.

Můžeme shrnout, že aktivní naslouchání otevírá dveře do seniorovy duše a naplňuje mnohé z jeho duchovních potřeb. Cestou aktivního naslouchání vedeného v respektu a lásce lze detekovat některá zranění duchovního či př́mo religiózního charakteru, která brání staršímu člověku otevř́t se vztahu s Bohem, ale i některé věroučné omyly, jež mají původ v povrchní dětské katechezi bez dalš́ho religiózního vedení (doslova tragický dopad mají mylné představy a předsudky ve vztahu ke svátosti smírení).

\section{Respekt k osobnímu př́běhu vývoje religiozity či spirituality}

Jako podstatný aspekt smysluplné pastorace je uváděn respekt k úrovni víry daného člověka. ${ }^{33}$ Ve stáři dostává toto doporučení další rozměr. Senioři mají za sebou podstatnou část života a k současné podobě víry dospěli cestou mnoha životních zkušeností, náročných životních okamžiků či rozhodnutí. P. Ambros poukazuje na to, že „životní př́iběh člověka a dějiny jeho víry jsou jedinou, nerozdělitelnou skutečností “. ${ }^{34}$ Boží vedení a Boží přítomnost se tak projevuje jak ve všedních každodenních událostech, tak v zásadních životních okamžicích a krizích. Přestože jsou senioři stále nejreligióznější skupinou v populaci (ve smyslu tradiční religiozity), není možné vycházet $\mathrm{z}$ předpokladu jakéhosi věkem daného stupně duchovní zralosti. Způsob prožívání religiozity či spirituality starších lidí je individuální právě proto, že je odrazem jejich životního př́běhu.

Porozumění životnímu příběhu konkrétního člověka jako podstatné součásti příběhu jeho víry je tak jedním z nezbytných aspektů smysluplného duchovního doprovázení. Také výsledky studie Duchovní potreby v životě jibočeských senioru odkryly výraznou variabilitu podoby religiozity starších křestanů (tedy těch, kteří byli pokřtěni): pro většinu z nich byl Bůh v jejich životě „nějak přítomen“, kontinuální religiózní praxi během života ale nezachovával ani jeden $\mathrm{z}$ nich.

\section{Odkrývání a posilování vlastních spirituálních zdrojů}

Obraz nemocného, závislého a osamělého vysokého stáří v kombinaci s velkou ochotou sloužit bližnímu může pastorujícímu zastřít velký potenciál starého člověka: jeho vnitřní sílu, nezdolnost, zkušenosti, strategie, silný osobní vztah k Bohu, schopnost hledat a vidět souvislosti a smysl svého životního příběhu, schopnost obětovat své trápení za druhé. Tento potenciál může být často skrytý a nepřiznaný a vhodně vedená pastorace může pomoci jeho rozvoji. 
Doprovázející by měl pomoci staršímu člověku naplno využít bohatství, které spočívá $\mathrm{v}$ duchovní oblasti jeho života. Duchovní intervence by měla směřovat zejména k posílení a rozvoji silných stránek charakteru, schopností a dovedností, $\mathrm{k}$ upevnění pozitivních postojů a hodnot, k posílení vědomí důstojnosti a sebedůvěry - např́íklad skrze schopnost být vděčný. Fišer uvádí praktický př́íklad denního rozjímání zaměřeného na posilování vlastních zdrojů skrze zakoušení vděčnosti: „Raději mysli na takové věci a děkuj za ně Bohu i lidem. Začni dneškem: Co pro tebe udělali druzí? Kdo se o tebe postaral? Kdo ti uvařil? Uklidil? Kdo tě navštívil? Kdo se na Tebe mile podíval? Každému ve svém srdci poděkuj. A za všechny a za všechno poděkuj Bohu! Ted' postupuj do minulosti a v modlitbě poděkuj všem svým nejbližším. (...) Vzpomeň si na všechno, co ti každý z nich udělal během poslední nemoci, za války a po ní, v letech totality, v jiných těžkých dobách - tady, kde žiješ, jinde, na cestách. Vrat se v myšlenkách do svého dětství a mládí. (...) Děkuj Bohu za to, že ti vždycky odpustil (...) nevracej se k hř́chům, které ti už byly dávno odpuštěny." ${ }^{35}$ Vděčnost umocňuje důvěru $\mathrm{v}$ Boží plán s člověkem, $\mathrm{v}$ jeho lásku $\mathrm{k}$ člověku, sebedůvěru, víru ve vyšší smysl života a vyšší realitu, jejižz jsem součástí. Je tak předpokladem k překonání nejen aktuálních pochyb o sobě samém, ale i bazální nedůvěry vzniklé v dětstvíi. ${ }^{36}$

Smyslem pastorace není učinit staršího člověka závislým na duchovním doprovázení (či na osobě pastoračního pracovníka), ale pomoci mu probudit a podpořit vlastní síly a duchovní zdroje ke smíření se svým životem, slidmi, s Bohem, ke smysluplnému zpracování vlastního příběhu, $\mathrm{k}$ nalezení či uchování si naděje a víry, uvědomění si vlastní důstojnosti, která není závislá na vnějších okolnostech či znalostech, výkonu a zásluhách. Pak také může naplnit úkoly, jež vyplývají z podstaty stáří a vztahují se k jeho vnitřnímu světu, ale také ven - k lidem v jeho okolí, k mladší generaci, $\mathrm{k}$ Bohu. ${ }^{37}$

\section{Závěr}

Přestože by kvalitní sociální péče měla zahrnovat člověka v jeho bio-psycho-socio-spirituální jednotě, v praxi domovů pro seniory je právě duchovní rozměr života př́slovečnou „popelkou“". Pastorace by neměla být jakousi další „sociální službou potřebným“, ale přirozenou součástí života $v$ daném zařízení. Staršílidé touží po kontaktu, potřebují zrcadlit své pocity, obavy, radosti, sdílet svá životní poznání a zkušenosti, potřebují mluvit o své rodině i o vztahu k Bohu, potřebují cítit opravdový zájem o svou osobu, lásku a podporu: „I řekl Hospodin Bůh: ,Není dobré, aby člověk byl sám““ (Gn 2,18). Metaforicky řečeno, jejich duše je hladová. Pastorační péče většinou nemůže odstranit těžkosti z života staršího člověka, ale může mu pomoci tyto obtíže důstojně zvládnout a smysluplně je integrovat do vlastního životního př́iběhu. Pevné spirituální ukotvení přispívá $\mathrm{k}$ vědomí vlastní důstojnosti, představuje důležitý zdroj jakéhosi vnitřního útočiště nezávislého na vnějších okolnostech, a je tak jakýmsi filtrem, přes který člověk posuzuje sám sebe.

Pastorující by si měl být vědom specifik stáří v oblasti fyzické, psychické, sociální i spirituální; jen tak může být starému člověku skutečným doprovázejícím partnerem, jen tak může

35 Zdeněk Cyril FIŠER, Plný život ve stárí, Kostelní Vydří: Karmelitánské nakladatelství, 2001, s. 34.

36 K tématu vztahu bazální důvěry popř. nedůvěry a podoby Božího obrazu více Karl FRIELINGSDORF, Falešné představy o Bobu, Kostelní Vydří: Karmelitánské nakladatelství, 2010, s. 173 aj.

37 Jak zdůrazňují veškeré v tomto článku zmíněné církevní dokumenty, starý člověk není (a neměl by být) jakýmsi „bezmocným“ pastoračním objektem, ale má velký potenciál být sám subjektem pastorace zejména ve své vrstevnické skupině. 
naplňovat pastorační událost, nejen literu. ${ }^{38}$ Necitlivá intervence, byt podložená znalostmi $z$ teologie a dobře míněná, může na dlouhou dobu uzavř́ít pomyslné dveře nitra staršího člověka a utvrdit jej v rozhodnutí setrvat v bezpečí soukromého „religiózního úkrytu“, kde není velký prostor pro duchovní růst - což je zcela v protikladu ke smyslu pastorace. Láska, respekt a uznání jedinečnosti životního př́běhu konkrétního člověka naopak otevírá cestu k duchovnímu růstu a př́padné společné „duchovní práci“. Podmínkou smysluplné péče o duchovní rozvoj člověka je tak jednak osobnostní vybavení a dobrá vůle, jednak odpovídající vzdělání - formální, neformální či zkušenostní.

Lidsky i duchovně zralý pastorační pracovník, znalý specifik stáří, může staršímu člověku zprostředkovat kontakt se skutečným evangeliem a dodat mu posilu v oblasti duchovních potřeb - jinak se zařadí do zástupu mnoha dalších, kteří se starým člověkem komunikují bez toho, že by ho skutečně viděli a slyšeli, a to i přesto, že tento pracovník v domově pro seniory „podává“, „vede zpěvy“, případně „slouží mši“.

\title{
Pastorace v domově pro seniory: vybrané otázky
}

\begin{abstract}
Abstrakt
Pastorace seniorů ve smyslu doprovázení staršího člověka v príběhu života i víry vyžaduje funkční vztah mezi pastorujícím a pastorovaným. Článek přináší nejprve stručnou reflexi současné praxe pastorační péče $v$ tuzemských domovech pro seniory jako specifického pastoračního prostředí, poté na základě závěrů kvalitativní studie Duchovní potřeby v životě jihočeských seniorů vymezuje a charakterizuje aspekty smysluplné pastorace (nejen) v tomto specifickém pastoračním prostředí: vlastní iniciativu pastorujícího $\mathrm{v}$ navázání kontaktu se seniory, východisko $v$ lásce $\mathrm{k}$ bližnímu, otevřenost vůči všem seniorům bez ohledu na deklarované vyznání, schopnost aktivního naslouchání jejich životnímu př́běhu, respekt k osobnímu př́běhu vývoje religiozity či spirituality konkrétního člověka a pomoc při odkrývání a posilování jeho vlastních spirituálních zdrojů.
\end{abstract}

Klíčová slova: stáŕí, domov pro seniory, pastorace, pastorační pracovník, duchovní potřeby

\section{Pastoral Care in Homes for the Elderly: Selected Issues}

\begin{abstract}
:
Pastoral care of the elderly in the sense of accompanying an older person in the story of life and faith requires a functional relationship between the pastoral worker and the recipient of pastoral care. The paper first brings a brief reflection of the contemporary practice of pastoral care in homes for the elderly in CR as a specific pastoral environment, then, based on the conclusions of the qualitative study Spiritual Needs in the Life of Elderly Persons in South Bohemia, defines and characterizes aspects of meaningful pastoral care (not only) in this specific pastoral milieu: own initiative of the pastoral worker in establishing contact with the

38 Srov. Pavel AMBROS, Dvojí tvář pastorace. Litera a duch, in: Pronikavá zmèna pastorace nebo sebezáchovný provoz? Být církví misionářrkým spioisobem: mez̧inárodní pastorálně teologické sympozium, eds. Zdeněk DEMEL - Karl SCHLEMMER, České Budějovice: Teologická fakulta Jihočeské univerzity, 2005, s. 115.
\end{abstract}


elderly persons, point of departure in love of the neighbour, openness to all elderly persons regardless of their declared creed, ability to actively listen to their life story, respect for the personal story of religious or spiritual development of the particular person and assistance in discovering and reinforcing his own spiritual resources.

Keywords: old age, home for the elderly, pastoral work, pastoral worker, spiritual needs

\section{Kontakt na autora}

\section{Mgr. Vèra Suchomelová, Th.D.}

Jihočeská univerzita v Českých Budějovicích

Teologická fakulta, Katedra pedagogiky

Kněžská 8, 37001 České Budějovice

suchomelova@seznam.cz 